\title{
Economic Growth Determinants of Asean Economic Community: Feasible Generalized Least Square Approach
}

\author{
Imamudin Yuliadi ${ }^{1, *}$, Wahdi Salasi April Yudhi ${ }^{2}$ \\ ${ }^{1}$ Department of Economics, Faculty of Economics and Business; Universitas \\ Muhammadiyah Yogyakarta, Indonesia \\ ${ }^{2}$ Sampoerna University, Jakarta, Indonesia
}

\begin{abstract}
This study aims to analyze the factors determining economic growth in ASEAN countries, which are the ASEAN economic community members as a potential center for world economic growth. The research method applied in this study was a panel data analysis model with a feasible generalized least square approach. The research period was from 2015 - 2019 in all ASEAN member countries: Indonesia, Myanmar, Malaysia, Singapore, Thailand, Laos, Vietnam, Cambodia, Brunei Darussalam, and the Philippines. Testing the data used the Chow and Hausman tests to determine the analysis method: fixed effect, random effect, or common effect. The results of panel data regression estimation with a feasible generalized least square approach uncovered that the variables of the number of the labor force, currency exchange rates, money supply (M1), exports, imports, Gini index, foreign debt, corruption perception index, financial literacy index, and foreign investment (PMA) significantly affected the economic growth of the ASEAN economic community, including develop agriculture sector. Meanwhile, the variables of domestic investment and financing credit did not affect the economic growth of the ASEAN economic community. The conclusion and recommendation from this study's results are each ASEAN country's efforts to encourage economic growth by utilizing its comparative advantages and strategic cooperation to create market opportunities and increase the economic efficiency of the ASEAN economic community.
\end{abstract}

\section{Introduction}

The ASEAN region is one of the centers of promising economic growth for the world's economy, which is currently experiencing stagnation due to the COVID-19 pandemic that has hit almost all countries in the world- With the potential for economic wealth, both natural resources and human resources, it is very promising for investment in this strategic area [2-8] Geographically, it is located between two continents, namely Asia and Australia, and two oceans, namely the Indian Ocean and the Pacific Ocean, placing the ASEAN region as a barometer for security and political stability in the Asia-Pacific [22-24] The

\footnotetext{
* Corresponding author: imamudin@umy.ac.id
} 
combination of the wealth of natural resources, the abundance of the workforce, political stability and security, and supported by a harmonious culture of society makes the ASEAN region one of the priorities of investors in investing in various economic sectors. The ASEAN region is also a center for trade and financial transactions and services to support the increasing demand for industrial goods and community needs $[10,14,19]$ The following table describes the development of the Gross Domestic Product of ASEAN countries:

Table 1. Gross Domestic Product in Selected ASEAN Countries (US\$ Billion)

\begin{tabular}{|c|c|c|c|c|c|}
\hline \multirow{2}{*}{ Year } & \multicolumn{5}{|c|}{ Country } \\
\cline { 2 - 6 } & Singapore & Malaysia & Thailand & Indonesia & Philippines \\
\hline 2010 & 239,809 & 255,017 & 341,105 & 755,094 & 208,369 \\
\hline 2011 & 255,008 & 268,517 & 343,971 & 801,682 & 216,408 \\
\hline 2012 & 266,836 & 283,214 & 368,884 & 850,024 & 231,334 \\
\hline 2013 & 279,272 & 296,507 & 378,797 & 897,262 & 246,950 \\
\hline 2014 & 290,269 & 314,318 & 382,526 & 942,185 & 262,626 \\
\hline 2015 & 294,944 & 330,321 & 394,514 & 988,129 & 279,299 \\
\hline 2016 & 308,640 & 345,020 & 408,043 & $1,037,860$ & 299,267 \\
\hline 2017 & 322,025 & 364,830 & 424,635 & $1,090,480$ & 320,009 \\
\hline 2018 & 333,096 & 382,129 & 442,621 & $1,146,850$ & 340,303 \\
\hline 2019 & 335,359 & 398,676 & 452,751 & $1,204,480$ & 360,859 \\
\hline
\end{tabular}

Source: worldbank.org, processed

The table above exhibits that until 2019, all member countries of the ASEAN economic community experienced an increase in GDP. When viewed from nominal figures, the largest GDP in 2019 was Indonesia. However, when viewed from the size of per capita income, the largest was Singapore. Looking at the GDP development from 2010-2019, the ASEAN region is a potential area in the world economy in developing the primary economic sector, namely food and energy products, and becoming an investment choice for the manufacturing and information technology-based industries. [15-20]

\section{Economic Models and Theoretical Frameworks}

Economic development is a long-term process to achieve economic prosperity for the whole community due to the interaction between economic and non-economic factors [20, 24]Economic development to improve people's welfare requires an increase in economic growth through production factors to produce goods and services. Economic growth is marked by increased per capita income from year to year, obtained through the gross domestic product (GDP) divided by the total population [16, 27]. Graphically, the process of economic growth is demonstrated by a shift to the top right of the production possibilities frontier, which indicates an increase in the production capacity of goods and services, as shown in the following curve: 


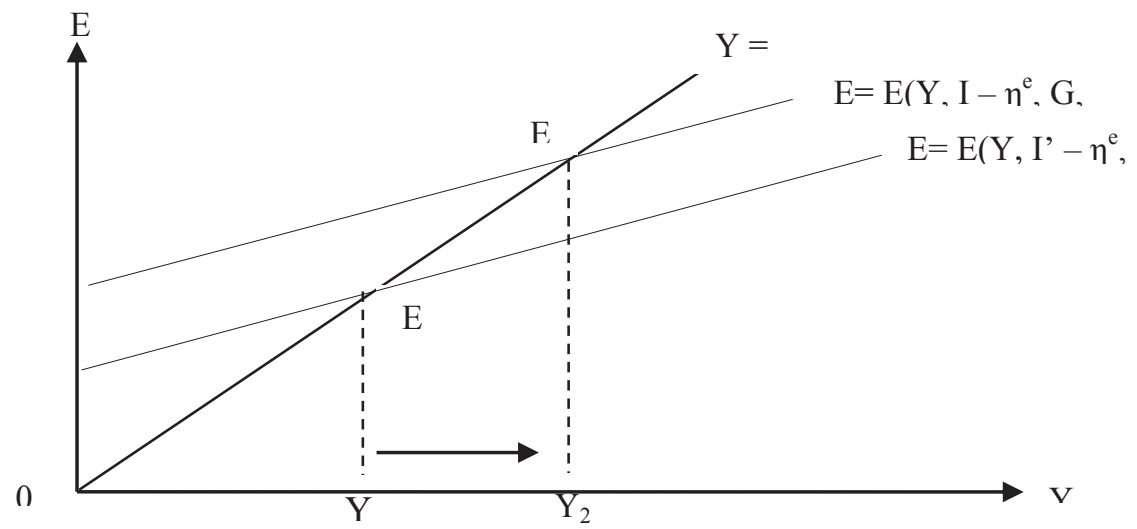

Fig. 1. Economic Growth

Source: David Romer, Advanced Macroeconomics, p. 201

The national income generated by an economy can be formulated through a CobbDouglass production function as follows:[37]

$$
\mathrm{Y}_{\mathrm{t}}=\mathrm{K}_{\mathrm{t}}^{\propto}\left(\mathrm{A}_{\mathrm{t}} \mathrm{L}_{\mathrm{t}}\right)^{1-\propto}, 0<\propto<1
$$

In which, $\mathrm{K}=$ capital input, $\mathrm{L}=$ labor input, $\mathrm{A}=$ technology level

Meanwhile, the national output is formed from household consumption expenditure (C), company investment expenditure (I), and government expenditure $(\mathrm{G})$, with $\delta$ indicating the amount of capital depreciation so that it can be formulated as:

$$
\begin{aligned}
& K_{t-1}=K_{t}+I_{t}+G_{t}-\delta K_{t} \\
& \quad=K_{t}+Y_{t}-C_{t}-G_{t}-\delta K_{t}
\end{aligned}
$$

The amount of wages (w) and the interest rate (r) is determined by the marginal product of the labor and capital inputs, namely: [37]

$$
\begin{gathered}
w_{t}=(1-\propto) K_{t}^{\propto}\left(A_{t} L_{t}\right)^{-\propto} A_{t} \\
=(1-\propto)\left(\frac{K_{t}}{A_{t} L_{t}}\right)^{\propto} A_{t} \\
r_{t}=\propto\left(\frac{A_{t} L_{t}}{K_{t}}\right)^{1-\propto}-\propto
\end{gathered}
$$

Furthermore, the expected household's maximum utility value can be formulated as follows:

$$
U=\sum_{k=0}^{\infty} e^{-p t} u\left(c_{t}, 1-\tau_{t}\right) \frac{N_{t}}{H}
$$

Where $\mathrm{N}=$ total population, $\mathrm{H}=$ number of households, $\mathrm{p}=$ discount rate. Population growth (n) exogenously can be formulated as follows: [27-31]

$$
\operatorname{Ln} N=\bar{N}+n t, \quad n<p
$$

By including the trend of economic growth and technological development, it is assumed that the economic model is not in shock so that it can be formulated as follows:

$$
\ln A_{t}=\bar{A}+g t+\tilde{A}_{t}
$$


In which: Ln $A_{t} g=$ technological development level, $\bar{A}=$ the effect of the shock

The formula above explains how economic growth occurs due to changes in the components that make up national income (GNP/GDP), namely consumption and investment, which are marked by an upward shift in the aggregate demand (AD) curve, thus pushing national income to the right from Y1 to Y2- [20-23] Meanwhile, the expenditure approach adds up all expenditures in the economy, comprising household consumption expenditures, corporate investment expenditures, government spending, and the foreign sector, namely exports minus imports, as in the following formula:[39]

Research on the economic growth determinants in ASEAN countries included the independent variables: population (POP), exports (X), foreign investment (FDI), foreign debt (HLN), money supply (JUB), interest rates (r), human development index (HDI), corruption perception index (GPA), financial literacy index (ILK), and energy consumption (KE). Meanwhile, the dependent variable was economic growth. The research model formulation with the dynamic panel data analysis model is:

$$
\begin{aligned}
\mathrm{Y}_{\mathrm{it}}= & \alpha+\beta_{1}(\mathrm{POP})_{i t}+\beta_{2}(\mathrm{X})_{i t}+\beta_{3}(\mathrm{FDI})_{i t}+\beta_{1}(\mathrm{HLN})_{i t}+\beta_{2}(\mathrm{JUB})_{i t}+\beta_{3}(\mathrm{r})_{i t}+\beta_{1}(\mathrm{IPK})_{i t}+ \\
& \left.\beta_{2}(\mathrm{IPM})_{i t}+\beta_{3} \mathrm{ILK}\right)_{i t}+\beta_{1}(\mathrm{KE})_{i t}+\text { et }
\end{aligned}
$$

Description:

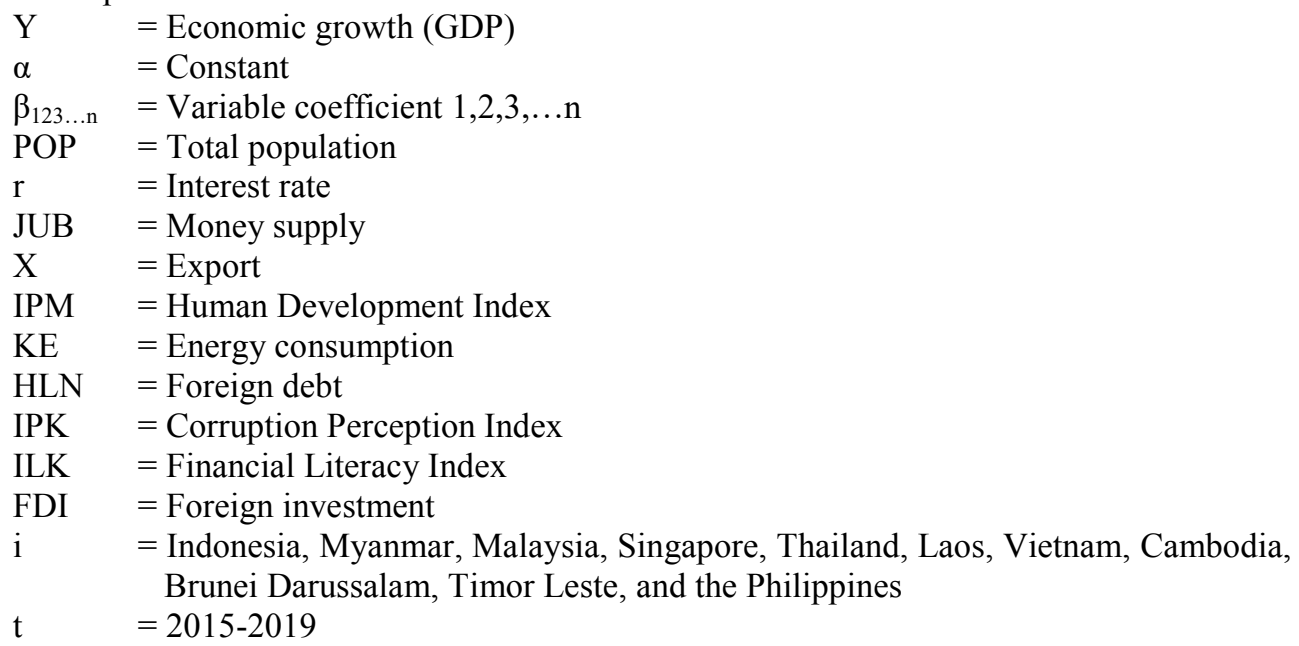

Economic growth is determined by factors that can increase the components constituting the national income, both economically and non-economically [16-22] The increase in consumption expenditure is determined by the national income, defined by the productivity of human resources in terms of the quality of education, health, and skills [40] In addition, the increase in corporate investment spending through the investment climate encourages investors' interest in investing and the ability of the financial sector to channel public savings into real economic sectors. Hence, in this case, investment is established by economic variables, namely the amount of public saving determined by the income and business efficiency of the financial and banking sectors in managing public savings funds to be channeled to the real sector. The intermediation function of banking institutions is regulated by banking management and macroeconomic policies carried out by the monetary authority in controlling the function of financial institutions as institutions that accommodate public funds and distribute them to the real sector [33-35] 


\section{Analysis Method}

The estimation of the regression coefficient in research on the economic growth determinants in the ASEAN economic community region using several economic variables by applying the least square method was formulated as follows:[31]

$$
\sum\left(Y_{i}-\hat{Y}\right)^{2}, \text { where } \hat{Y}_{i}=a+b X_{i} \in_{t}^{-2}
$$

The formulation to determine the values of constant (a) and regression coefficient (b) is as follows:[31]

$$
\begin{aligned}
& \frac{\partial}{\partial b} \sum\left(Y_{i}-a-b X_{i}\right)^{2}=-2 \sum\left(Y_{i}-a-b X_{i}\right) \\
& \frac{\partial}{\partial b} \sum\left(Y_{i}-a-b X_{i}\right)^{2}=-2 \sum\left(Y_{i}-a-b X_{i}\right) \\
& \sum\left(Y_{i}-a-b X_{i}\right)=0 \\
& \sum X_{i}\left(Y_{i}-a-b X_{i}\right)=0 \\
& \sum Y_{i}=a N+b \sum X_{i} \\
& \sum X_{i} Y_{i}=a \sum X_{i} \pi r^{2} Y_{i}+b \sum X_{i}^{2}
\end{aligned}
$$

To solve the simultaneous equations with the least-squares approach, the following formula was put together:

$$
\begin{aligned}
& \sum X_{i} \sum Y_{i}=a N \sum X_{i}+b\left(\sum X_{i}\right)^{2} \\
& N \sum X_{i} \sum Y_{i}=a N \sum X_{i}+b N \sum X_{i}^{2} \\
& N \sum X_{i} Y_{i}-\sum X_{i} \sum Y_{i}=b\left\{N \sum X_{i}^{2}-\left(\sum X_{i}\right)^{2}\right\}
\end{aligned}
$$

From the above formula, the constant (a) and regression coefficient (b) values could be obtained as follows:[31]

$$
\begin{aligned}
& b=\frac{N \sum X_{i} Y_{i}-\sum X_{i} \sum Y_{i}}{N \sum X_{i}^{2}-\left(\sum X_{i}\right)^{2}} \\
& a=\frac{\sum Y_{i}}{N}-b \frac{\sum X_{i}}{N}
\end{aligned}
$$

The estimation of panel data analysis utilizing the fixed effect model assumes differences between individual times in the data studied. In this study, the Least Square Dummy Variable (LSDV) approach was indicated by the difference in the intercept, defined with the following matrix:[31-35]

$$
\left[\begin{array}{l}
Y_{1} \\
Y_{2} \\
Y_{3}
\end{array}\right]=\left[\begin{array}{l}
a \\
a \\
a
\end{array}\right]+\left[\begin{array}{lll}
1 & 0 & 0 \\
0 & 1 & 0 \\
0 & 0 & 1
\end{array}\right]+\left[\begin{array}{l}
a_{1} \\
a_{2} \\
a_{3}
\end{array}\right]+\left[\begin{array}{lll}
X_{1.1} & X_{2.1} & X_{1.1} \\
X_{1.2} & X_{2.2} & X_{1.1} \\
X_{1.3} & X_{2.3} & X_{1.1}
\end{array}\right]+\left[\begin{array}{l}
\beta_{1} \\
\beta_{1} \\
\beta_{1}
\end{array}\right]+\left[\begin{array}{l}
\beta_{1} \\
\beta_{1} \\
\beta_{1}
\end{array}\right]
$$

Based on the Chow test results, it is known that the probability value was $<0.05$, meaning that the valid model for panel data analysis in this study was the fixed effect model. Meanwhile, the Hausman test results revealed a probability value of $>0.05$, indicating that the valid model in this study was the random effect model. In addition, the Lagrange Multiplier (LM) test results stated that the probability value was $<0.05$, signifying that the valid model was a random effect model. [33-35]

\section{Empirical Findings}

The estimation results of research panel data analysis on the economic growth determinants of the ASEAN economic community with the feasible generalized least square (FGLS) approach are as follows: 
Table 2. Panel Data Analysis Model Estimation of Economic Growth Determinants in ASEAN Countries

\begin{tabular}{|c|c|}
\hline \multirow{2}{*}{ Dependent Variable: } & Feasible Generalized Least Square \\
\hline & Coefficient \\
\hline Constant & -10.6613 \\
\hline Probability & 0.000 \\
\hline Population & $0.9463 * * *$ \\
\hline Probability & 0.000 \\
\hline Money supply & 0.0764 \\
\hline Probability & 0.215 \\
\hline Foreign debt & 0.0327 \\
\hline Probability & 0.609 \\
\hline FDI & $0.0418^{*}$ \\
\hline Probability & 0.063 \\
\hline Export & -0.0035 \\
\hline Probability & 0.296 \\
\hline HDI & $8.4018^{* * *}$ \\
\hline Probability & 0.003 \\
\hline Interest rate & -0.0018 \\
\hline Probability & 0.960 \\
\hline Corruption Perception Index & 0.0113 \\
\hline Probability & 0.354 \\
\hline Financial Literacy Index & 0.0003 \\
\hline Probability & 0.428 \\
\hline Energy consumption & -0.0003 \\
\hline Probability & 0.965 \\
\hline Timedummy 2 & -0.0560 \\
\hline Probability & 0.801 \\
\hline Timedummy3 & -0.1339 \\
\hline Probability & 0.558 \\
\hline Timedummy4 & -0.3359 \\
\hline Probability & 0.147 \\
\hline Timedummy5 & -0.1330 \\
\hline Probability & 0.561 \\
\hline Timedummy6 & $-0.4052 *$ \\
\hline Probability & 0.085 \\
\hline Timedummy 7 & $-0.6654 * * *$ \\
\hline Probability & 0.009 \\
\hline Timedummy8 & $-0.4318^{*}$ \\
\hline Probability & 0.074 \\
\hline Timedummy9 & -0.1315 \\
\hline Probability & 0.598 \\
\hline Timedummy10 & -0.2007 \\
\hline Probability & 0.442 \\
\hline Wald $\chi^{2}$ & $893.94 * * *$ \\
\hline Probability & 0.000 \\
\hline Log Likelihood & -69.8156 \\
\hline
\end{tabular}

Source: World Bank (processed), Description: $* * *=$ significant if $\alpha=0.01$, $* *=$ significant if $\alpha=0.05, * \quad=$ significant if $\alpha=0.10$ 
In research on the economic growth determinants in the ASEAN economic community, the dependent variable was economic growth (GDP). In contrast, the independent variables consisted of the population (POP), exports (X), foreign investment (FDI), foreign debt (HLN), money supply (JUB), interest rate (r), corruption perception index (GPA), human development index (HDI), financial literacy index (ILK), and energy consumption (KE). The estimation results by applying the feasible generalized least square (FGLS) model uncovered that there were only six independent variables that showed a significant influence on the economic growth of the ASEAN economic community: population (POP), foreign investment (FDI), human development index (IPM), timedummy year-6, timedummy year-7, and timedummy year-8. These empirical findings indicate that demographic factors are influential on economic growth in the ASEAN economic community. This sociological phenomenon also signifies that the ASEAN economic community member countries could take advantage of the demographic bonus momentum to encourage economic growth, including develop agriculture sectors.[17-24] In addition, the regression coefficient value of the population variable was 0.9463 . It means that an increase in the population of one million people will increase economic growth in the ASEAN economic community by 0.946 billion US dollars. This phenomenon also denotes how the ASEAN economic community countries have become centers of world economic growth by taking advantage of their large population. The population strength is mainly to support the small and medium economic sector, which is labor-intensive. Likewise, in the agricultural, plantation, and fishery sectors, it is to process the natural resources results to produce primary products or meet industrial needs. Moreover, the large population is the economic driver of the ASEAN economic community through its involvement in all economic sectors, which are being intensively carried out, such as the infrastructure construction for the education sector, transportation, health, irrigation canals, housing, office buildings, etc. [6-10]

In this study, the foreign investment variable (FDI) had a positive and significant effect on the economic growth of ASEAN countries, with a coefficient value of 0.0327 . It means that an increase in foreign investment of one billion US dollars will increase economic growth by 0.0327 billion US dollars. In this regard, the entry of foreign investment in the ASEAN economic community countries is a driver of economic growth in the region because ASEAN countries - except Singapore - face the capital scarcity problem. This phenomenon is a crucial economic development issue in developing countries - including ASEAN countries - to encourage economic growth. Capital scarcity results from a lack of public savings funds entering the money market, both in the banking and capital markets. This condition occurs as some developing countries face the problem of community lowincome levels so that the funds that can be saved are relatively small. Another factor is the lack of strength in the financial sector in meeting the community needs to save money in banks and the ability of banks to channel financing funds to the real sector.

Furthermore, the variable human development index (HDI) is an essential factor to encourage the economic growth of the ASEAN economic community. It emphasizes the importance of the quality of human resources as the primary factor to encourage economic growth in ASEAN countries. In this study, the regression coefficient of the HDI variable was 8.4018, indicating that an increase in the HDI index will increase the economic growth of the ASEAN economic community countries by 8.4018 billion US dollars. In this case, the phenomenon of the quality of human resources is a crucial issue in ASEAN countries since the main factor of economic development lies in the quality of human resources, which relies on health, education, and ability aspects to adapt to changes in the global economic environment. However, the low quality of human resources is indicated by many residents in several ASEAN countries who only reach the high school level and have not had time to enjoy educational facilities up to university. For this reason, improving the 
quality of human resources through improving the quality of education and health will impact increasing economic productivity, encouraging economic growth in the ASEAN economic community countries. [37-42]

The regression estimation results also disclosed that the dummy variables in the 6th, 7 th, and 8 th years showed a significant value. It signifies that in the period of the 6 th, 7 th, and 8th years, there was an increase in the economy in the ASEAN economic community countries. The regression coefficient value of the 6th year dummy variable was -0.4052 , and with a constant value of -10.6613 , the number was -11.0665 . If the antilog value was searched and multiplied by the GDP value, the mean value was 0.976 . It means that in the 6th year, the average economy in the ASEAN economic community countries increased by 0.976 billion US dollars. Meanwhile, the regression coefficient value for the 7 th year dummy variable was -0.6654 , and the mean economic growth of ASEAN countries was 11.3267. If looking for the antilog value and multiply it by the GDP value, the mean value was 1.77 , meaning that in the 7 th year, the average economy in the ASEAN economic community countries increased by 1.77 billion US dollars. Furthermore, the regression coefficient value of the dummy variable in the 8 th year was -0.4318 , and with a constant value of -10.6613 , the number was -11.0931. If the antilog value was searched and multiplied by the GDP value, the mean value was 1.67 . It indicates that in the 7 th year, the average economy of the ASEAN economic community countries increased by 1.67 billion US dollars. This phenomenon signifies that the economies of the ASEAN economic community countries are heterogeneous between developed countries, such as Singapore, Malaysia, and Thailand, and still relatively lagging countries, for instance, Cambodia, Vietnam, Laos, and Myanmar. Moreover, ASEAN is a region that has become a crossroads of international trade traffic and is increasingly open to turmoil in the global market. The impact on the ASEAN countries' economies would begin to be felt by the ASEAN economic community countries in the 6 th year. Meanwhile, from the 2 nd year to the 5 th year, it was not shown any influence on the economic conditions of the ASEAN economic community countries. This condition is related to the economic crisis that runs periodically for 4-5 years, as has happened before. In addition, it is also influenced by the burden of foreign debt borne by the ASEAN economic community countries, which are due to pay off the principal and interest. [43-46]

\section{Conclusion and Recommendation}

Empirical findings from research on the economic growth determinants in ASEAN economic community countries revealed the importance of investment factors and the quality of human resources (HR) as vital factors in promoting economic growth. The development of the quality of human resources through improving the quality of education and training and the opportunity to develop learning experiences in the world of industry and work will increase the human resource capacity of the ASEAN economic community countries, including develop agriculture sector that contribute big contribution on regional economic. In addition, the adaptation of human resources to technology and information development can be a medium to strengthen capacity in seizing existing economic opportunities. On the other side, policies to attract investors, both domestic and foreign, by continuously improving the investment climate through a more accessible and more efficient licensing process, eliminating rent-seeking and corrupt practices, and improving the quality and capacity of infrastructure will have an impact on increasing economic efficiency. Another essential thing is how to optimize the multiplier impact of foreign and domestic investment on local economic potential so that it can influence regional economic growth and equity. Moreover, it is necessary to find a formula to build a synergy between the government and the business world in strengthening the macroeconomic fundamentals 
of ASEAN countries in the face of economic disruption, which has the potential to damage the stability and sustainability of economic development in the ASEAN economic community countries. [14, 25, 49]

\section{References}

1. Adams, R. H., \& Page, J. (2005). Do international migration and remittances reduce poverty in developing countries? World Development, 33(10), 1645-1669. DOI: https://doi.org/10.1016/j.worlddev.2005.05.004

2. Adema, W., \& Ladaique, M. (2009). How Expensive is the Welfare State? DOI: doi:https://doi.org/10.1787/220615515052

3. Andrew Reschousky and Susan J Zahner, 2016, Forecasting The Revenue of Local Public Health Department in The Shadow of The Great Recession, Journal Public Health Management Practice, 22(2), p. 120-128

4. Barrett, A., Kahanec, M., Zimmermann, K. F., Giulietti, C., \& Guzi, M. (2013). Unemployment benefits and immigration: evidence from the EU. International Journal of Manpower, 34(1), 24-38. DOI: https://doi.org/10.1108/01437721311319638

5. Burakov, D. (2017). Oil prices, economic growth and emigration: An empirical study of transmission channel. International Journal of Energy Economics and Policy, 7(1), 90-98.

6. Çatalbaş, G. K., \& Yarar, Ö. (2015). Determination of Factors Affecting Internal Migration in Turkey with Panel Data Analysis. Alphanumeric Journal, 3(1), 99-117. DOI: http://dx.doi.org/10.17093/aj.2015.3.1.5000113446

7. Chernick, Howard, Laucley, Adam, Reschovsky, Andrew, 2012, Predicting The Impact of The US Housing Crisis and Great Recession on Central City Revenue, Publius The Journal of Federalism, 42(3), p. 467-493

8. Devlin, C., Bolt, O., Patel, D., Harding, D., \& Hussain, I. (2014). Impacts of migration on UK native employment: An analytical review of the evidence: Home Office London.

9. Diallo, S. (2017). The Role of Human Capital in Guinea's Economic Growth an Empirical Analysis of The Educations Effect on Technological Progress over The Period 1980-2010, 45.International Journal of Economic Development

10. Epaphra, M. (2018.). An Econometric Analysis of The Determinants of Foreign Direct Investment in Africa, International Journal of Development Economics

11. Fafurida F and Pratiwi EN, 2017, Financial Independent of Regencies and Cities in Central Java, Economic Journal of Emerging Markets, 9(2), p. 199-209

12. Fasani, F., Frattini, T., \& Minale, L. (2017). The (struggle for) labour market integration of refugees: Evidence from European countries: Centre for Research and Analysis of Migration (CReAM), Department of ....

13. Fernando Alexandre, Helder Costa, Miguel Portela, Miguel Rodrigues, 2019, Asymmetric Regional Dynamics in The Portuguese Economy Debt, Openness and Local Revenues, Regional Studies Association, Vol. 54, issue 10

14. Gherghina, R, 2013, The Contribution of Education to The Economics Development Process of State, Journal of Knowledge Management Studies and Information Technology, 3(1), 211-223

15. Ginting, S, Charisma Kuriata, Irsad Lubis and Kasyful Mahalli, 2008, Human Development in Indonesia and Factors Affecting, Journal of Planning and Regional Development, Vol. 4, No. 1, p. 17-24 
16. Gray, C., \& Bilsborrow, R. (2013). Environmental Influences on Human Migration in Rural Ecuador. Demography, 50(4), 1217-1241. DOI: 10.1007/s13524-012-0192-y

17. Hanley, J., Ives, N., Lenet, J., Hordyk, S.-R., Walsh, C., Soltane, S. B., \& Este, D. (2019). Migrant women's health and housing insecurity: an intersectional analysis. International Journal of Migration, Health and Social Care, 15(1), 90-106. DOI: https://doi.org/10.1108/IJMHSC-05-2018-0027

18. Hollis, J. (2019). The psychosocial experience of UK immigration detention. International Journal of Migration, Health and Social Care, 15(1), 76-89. DOI: https://doi.org/10.1108/IJMHSC-04-2018-0024

19. Hossain, M. Z. (2001). Rural-urban migration in Bangladesh: a micro-level study. Paper presented at the Brazil IUSSP conference. August.

20. Kei Imakubo, Jouchi Nakajima, 2015, Estimating Inflation Risk Premia from Nominal and Real Yield Curves using a Shadow Rate Mode, Bank of Japan Working Papers Series, Tokyo,

21. Kerr, S. P., \& Kerr, W. R. (2011). Economic impacts of immigration: A survey. Finnish Economic Paper, 24(1), 1-32.

22. Koichiro Kamada, Jouchi Nakajima, 2013, On The Reliability of Japanese Inflation Expectation Using Purchasing Power Parity, Bank of Japan Working Papers Series, Tokyo,

23. Kotarba B and Kolomvcew A, 2014, Financial Independence of Local Government Units in Poland, Journal of Universal Excellence, vol 3(4), p. 101-104

24. Lu, Y. (2010). Rural-urban migration and health: Evidence from longitudinal data in Indonesia. Social Science \& Medicine, 70(3), 412-419. DOI: https://doi.org/10.1016/j.socscimed.2009.10.028

25. Lumpe, C. (2007). The labour market impact of immigration: theory and evidence. Diskussionspapier der Forschergruppe, 1-60. doi: http://nbnresolving.de/urn:nbn:de:bsz:352-opus-39438

26. Lutz, Byron F, 2012, The Connection between House Price Appreciation and Property Tax Revenues, National Tax Journal, 6(3), p. 555-572

27. Lutz, Byron F, Molloy, Raven, Shan, Hui, 2011, The Housing Crisis and State and Local Government Tax Revenue Five Channels, Regional Science and Urban Economics, 41(4), p. 306-319

28. Maleku, A., Kim, Y. K., \& Lee, G. (2019). Social cohesion and immigrant health: does language-efficacy matter? International Journal of Migration, Health and Social Care, 15(1), 17-30. DOI: https://doi.org/10.1108/IJMHSC-02-2018-0007

29. Martin, P. L., \& Zürcher, G. (2008). Managing migration: The global challenge (Vol. 63): Citeseer.

30. Mayda, A. M. (2010). International migration: A panel data analysis of the determinants of bilateral flows. Journal of Population Economics, 23(4), 1249-1274. DOI: $10.1007 / \mathrm{s} 00148-009-0251-\mathrm{x}$

31. Michael Intriligator, Ronald Bodkin, Cheng Hsiao, 1996, Econometric Models, Techniques and Applications, Prentice Hall International Editions

32. Mirza, Dennis, 2012, Effect of Poverty, Economic Growth and Capital Expenditure against Human Development Index in Central Java 2006-2009, Development Economic Analysis Journal, 1(2),

33. Mogues T and Benin, 2012, Do External Grants to District Government Discourage Own Revenue Generation ?, A Look at Local Public Finance Dynamics in Ghana, 
World Bank, 40(5), p. 1054-1067

34. Murtin F and Wacziarg, R, 2014, The Democratic Transition, Journal of Economic Growth, 19, p. 141-181

35. Ozekhome, H. O. (2017). Exchange Rate, Trade and Macroeconomic Stabilization Evidence from Nigeria, 25, International Journal of Economic Development

36. Pimentel, M. S., Harper, B., \& Martin, E. J. (t.t.). Addressing Poverty in Peru Degrowth Indigenous Local Farming and Technology Innovation, International Journal of Economic Development

37. Polillo, A., Kerman, N., Sylvestre, J., Lee, C. M., \& Aubry, T. (2018). The health of foreign-born homeless families living in the family shelter system. International Journal of Migration, Health and Social Care, 14(3), 260-268. DOI: https://doi.org/10.1108/IJMHSC-11-2017-0048

38. Romer, David, 1976, Advanced Macroeconomics, McGraw-Hill International Editioins

39. Thomas A. Lubik. (2018). Indeterminacy and Learning: An Analysis of Monetary Policy in the Great Inflation, International Journal of Monetary Economics

40. Tombe, T., \& Zhu, X. (2019). Trade, migration, and productivity: A quantitative analysis of china. American Economic Review, 109(5), 1843-1872. DOI: 10.1257/aer.20150811

41. Vitale, M., \& Doherty, S. T. (2018). Lifestyle and weight changes among immigrants in Canada. International Journal of Migration, Health and Social Care, 14(4), 439454. DOI: https://doi.org/10.1108/IJMHSC-04-2018-0023

42. Vujicic, M., Zurn, P., Diallo, K., Adams, O., \& Dal Poz, M. R. (2004). The role of wages in the migration of health care professionals from developing countries. Human resources for health, 2(1), 3. DOI: 10.1186/1478-4491-2-3

43. Wood, B. M., \& Kallestrup, P. (2018). A review of non-specialised, group-based mental health and psychosocial interventions in displaced populations. International Journal of Migration, Health and Social Care, 14(3), 347-359. DOI: https://doi.org/10.1108/IJMHSC-02-2018-0010

44. Yalaz, E., \& Zapata-Barrero, R. (2018). Mapping the qualitative migration research in Europe: An exploratory analysis Qualitative research in European migration studies (pp. 9-31): Springer.

45. Yuliadi, Imamudin, 2020, Determinants of Regional Economics Growth in Indonesia, Jurnal Ekonomi dan Studi Pembangunan (JESP), Vol. 21, No. 1, p. 125-136

46. ----- 2020, The Analysis of Money Supply in Indonesia Vector Autoregressive (VAR) Approach, Journal of Asian Finance Economic and Business (JAFEB), Vol. 7, No. 7, 241, p. 241-249

47. --------------, 2020, The Implementation of Dual Monetary System in Indonesia, International Journal of Economics and Business Administration (IJEBA), Vol. 3, p. 28-39

48. 2020, Migration and Income Inequality in Indonesia Longitudinal Data Analysis, Journal of Asian Finance Economics and Business (JAFEB), Vol. 7, No. 11, 541, p. 541-548

49. Zhang, W.-B. (2016.). Spatial agglomeration in a monetary multi-regional growth model with urban residential distribution, 28. 